\title{
Putative Biomarkers and Targets of Estrogen Receptor Negative Human Breast Cancer
}

\author{
Ziad J. Sahab ${ }^{1} *$, Yan-Gao Man ${ }^{2,3}$, Stephen W. Byers ${ }^{1}$ and Qing-Xiang A. Sang ${ }^{4}$
}

1 Department of Oncology, Lombardi Comprehensive Cancer Center, Georgetown University Medical Center, Washington, DC 20007, USA; E-Mail: byerss@ georgetown.edu

2 Diagnostic and Translational Research Center, Henry Jackson Foundation for the Advancement of Military Medicine, Gaithersburg, MD 20789, USA; E-Mail: ymann@ @jfresearch.org

3 Jilin University, Changchun 130012, China

4 Department of Chemistry and Biochemistry and Institute of Molecular Biophysics, Florida State University, 102 Varsity Way, Tallahassee, FL 32306, USA; E-Mail: qxsang@chem.fsu.edu

* Author to whom correspondence should be addressed; E-Mail: zjs3@ georgetown.edu; Tel.: +1-202-687-1891; Fax: +1-202-687-7505.

Received: 28 April 2011; in revised form: 27 June 2011 / Accepted: 4 July 2011 / Published: 13 July 2011

\begin{abstract}
Breast cancer is a progressive and potentially fatal disease that affects women of all ages. Like all progressive diseases, early and reliable diagnosis is the key for successful treatment and annihilation. Biomarkers serve as indicators of pathological, physiological, or pharmacological processes. Her2/neu, CA15.3, estrogen receptor (ER), progesterone receptor (PR), and cytokeratins are biomarkers that have been approved by the Food and Drug Administration for disease diagnosis, prognosis, and therapy selection. The structural and functional complexity of protein biomarkers and the heterogeneity of the breast cancer pathology present challenges to the scientific community. Here we review estrogen receptor-related putative breast cancer biomarkers, including those of putative breast cancer stem cells, a minor population of estrogen receptor negative tumor cells that retain the stem cell property of self-renewal. We also review a few promising cytoskeleton targets for ER alpha negative breast cancer.
\end{abstract}

Keywords: biomarker; breast cancer; chromatography; DCIS; electrophoresis; estrogen receptor; metastasis; proteomics 


\section{Introduction}

Cancer cells frequently exhibit unique gene expression profiles resulting not only in their limitless replication, but also in their ability to actively attack other tissues, recruit the collaborating cells necessary for sustained angiogenesis, and afford them protection from the host immune system [1]. Consequently, on the molecular level, tumors are never silent, but are constantly signaling their presence through the release of a diverse range of enzymes, modulators, and mediators [2]. Breast cancer is a heterogeneous disease. Some breast cancer cells lose their ability to express ER $\alpha$, among other proteins. The resulting disease is a therapy-resistant cancer. To identify human breast cancer biomarkers between $\mathrm{ER} \alpha(+)$ and $\mathrm{ER} \alpha(-)$ breast tumors, tissues were microdissected and differential protein expression by adjacent tissues was identified [3], microdissected breast tissues composed of either normal ductal epithelium or ductal epithelium containing Ductal Carcinoma in situ (DCIS) lesions were also compared [4]. The heterogeneity of breast cancer architecture is currently hindering proteomics research in this area [5]. Promising new biomarker identification methodologies are under way like lectin glycoarray technology [6], microfluidic-based biosensors [7], lectinomics [8], gold nanoparticles [9-11], enrichment of low-abundance proteins [12-20], and dye-doped silica nanoparticle labels [21].

\section{Estrogen Receptors}

Estrogens play a major role in the development of sexual glands and the reproductive cycle [22], with their biological effects mediated through the estrogen receptor (ER). ER $\alpha$, cloned in 1986 [23,24], was believed to be the sole form of this receptor until 1996, when a second ER, called ER- $\beta$, was also cloned [25,26]. Since that time, five ER $\beta$ isoforms (ER $\beta 1$ through ER $\beta 5)$ have been cloned and characterized, and their nucleotide sequences are consistent with the incorporation of different exons [27]. The exact roles of ER $\alpha$ and ER $\beta$ in breast cancer are still unknown, though it has been reported that estrogens are involved in the promotion of human breast cancer, possibly by way of their mitogenic activity. ER $\alpha$ and ER $\beta$ have structural domains that are not conserved [26] and have different transcriptional activity [28] and ligand binding affinity [29]. ER $\beta$ requires higher levels of estrogens for activation than does ER $\alpha$ and acts as a transdominant inhibitor of ER $\alpha$ in near-saturating hormone levels [30]. Different forms of the ER are therefore likely to mediate signal transduction in very different fashions, and understanding the role of each ER in the pathogenesis of breast cancer is vital in the development of estrogens for use in long-term hormone replacement regimens that do not promote breast cancer [31]. Studies performed with mice indicate that ER $\alpha$ mediates the major proliferative effects of estrogen, as ER $\alpha$ knockout mice exhibit rudimentary mammary glands and infertility [32,33]. In contrast to this finding, ER $\beta$ knockout mice showed normal mammary gland development, but significantly reduced fertility [34]. These studies suggest distinct but overlapping biological actions for these two receptors.

Several in vitro studies have been performed to study the effects of these two ERs in human breast cancer cells. Studies with MCF-7 breast cancer cells, which express ER $\alpha$, revealed that estradiol stimulates proliferation in these cells [35]. Additional studies with the MCF-7 cell line revealed cessation of proliferation when the ER $\alpha$ gene was knocked out, and a resumption of proliferation when 
the ER $\alpha$ gene was reintroduced [36]. A recent study utilizing ER $\beta$-transfected MCF-7 cells showed inhibition of proliferation in vitro and tumor formation in vivo in a nude mouse xenograft model in response to estradiol [31]. Studies performed with cervical cancer-derived HeLa cells indicate that estrogens activate cyclin D1 when complexed with ER $\alpha$. However, the expression of cyclin D1, a major regulator for entry into the proliferative stage of the cell cycle, is inhibited in the presence of ER $\beta$ [37]. In vitro studies using the breast cancer cell line T47D have shown reduced estradiol-stimulated proliferation when the expression of ER $\beta$ mRNA equals that of ER $\alpha$. This reduction in proliferation correlates with a decrease in proliferation-associated cell cycle components such as cyclin E, Cdc25A, and Cdk2 [38]. Additional studies utilizing the MDA-MB-231 breast cancer cell line have shown that ER $\alpha$ and ER $\beta$ are capable of reversing the invasive phenotype of this breast cancer cell line by inhibiting migration and invasion [39]. Combined, these studies suggest that ER $\alpha$ and ER $\beta$ may have opposing effects in terms of breast cancer cell proliferation, but similar effects in terms of in vitro inhibition of migration and invasion.

Immunohistochemical staining for ER $\beta$ in normal human breast tissues, DCIS, invasive cancers, and lymph node metastases has revealed a gradual reduction in ER $\beta$ expression during the transition from normal tissue to pre-invasive lesions to invasive cancers, with ER $\beta$ completely absent in $21 \%$ of the invasive cancers studied [40]. Another study utilizing similar techniques revealed that the percentage of cells positive for ER $\beta$ was high in normal mammary glands and non-proliferative benign breast disease, but decreased significantly in proliferative benign breast disease and carcinoma in situ. The ratio between ER $\beta$ and ER $\alpha$ was high in normal glands, but decreased significantly in proliferative lesions [41]. These results are in agreement with results obtained using in situ hybridization to investigate mRNA levels of ER $\beta$ in normal mammary, benign breast disease, breast cancer, and metastatic lymph nodes [42]. In situ hybridization revealed that ER $\beta$ expression was significantly decreased in breast cancer and metastatic lymph node tissues when compared with normal mammary and benign breast disease tissues. All of these results suggest that ER $\beta$ might exert a protective effect against the mitogenic activity of estrogens mediated by ER $\alpha$, and may therefore function as a tumor suppressor, as the loss of ER $\beta$ expression seems to correlate with the progression of breast carcinomas.

A small fraction of in situ ER $\alpha$ negative breast tumor cell clusters showed signs of stromal and vascular invasion but lacked many differentiation markers, suggesting that these clusters may contain mutated stem cells [43]. Cancer stem cells are a minor population of tumor cells that retain the stem cell property of self-renewal. However, pathways regulating this process in normal stem cells are deregulated in cancer stem cells, leading to the continuous expansion of self-renewing cancer cells and new tumor cluster formation [44]. Targeting cancer stem cells may improve the effectiveness of cancer therapies [45]. Although beyond the scope of this review, it is important to note that ER negative breast cancer cells can later revert back to ER positive cancer following trastuzumab and chemotherapy treatment, except for triple negative breast cancers [46], and putative estrogen receptor positive breast cancer stem cells have been identified [47].

\section{Putative ERa Breast Cancer Biomarkers}

Differential protein expression between ER(+) and ER(-) tissues has been investigated [43,48-54]. Loss of TIP30 enhances the activation of Akt signaling, leading to the development of ER+/PR- 
mammary tumors [55]. The key driver of the proliferation of $E R \alpha(+)$ is the high expression of microRNA miR-375 [56]. Overexpression of HIF1 in ER $\alpha(+)$ cells cooperates with ER and hypoxia to promote breast cancer progression [57,58]. Contrary to $\operatorname{ER} \alpha(-)$ breast tumors, $\mathrm{ER} \alpha(+)$ cells have low levels of 611-CTF, a Her2 C-terminal fragment that induces resistance to anti-estrogen therapies [59]. The highest levels of cell proliferation have been observed in invasive carcinomas with increased $\mathrm{ER} \alpha(+)$ expression [60]. Levels of $\mathrm{ER} \alpha(+)$ are regulated by immunophillin FKBPL, an estrogen receptor gene. Cells expressing FKBPL are more sensitive to anti-estrogen therapies [61]. Ronneberg et al have conducted a study to analyze gene methylation and its correlation with ER status [62]. They found $171 \mathrm{CpG}$ sites representing 151 Entrez Gene IDs that were differentially methylated between $\mathrm{ER} \alpha(+)$ and $\mathrm{ER} \alpha(-)$ breast cancers with the following $\mathrm{CpG}$ sites hypermethylated in ER+ tumors: STAT5A, WNT1, DAPK1, ALPL, IFNGR2, IGFBP7, ST6GAL1 and TMEFF1.

CXCR4 overexpression has been shown to promote estrogen independence in vivo [63]. Inhibiting telomerase activity has shown efficiency for treating $\mathrm{ER} \alpha(-)$ cells [64]. Estrogen receptor negative breast cancers have been associated with focal myoepithelial disruption, a lack of expression of tumor suppressors, and a higher rate of cell proliferation [48,65-71]. Furthermore, the vast majority of cell budding in breast cancer ducts is driven by $\operatorname{ER} \alpha(-)$ cells [49]. BP1 was found to be overexpressed in $\mathrm{ER} \alpha(-)$ tumors and results in significantly enhanced cell proliferation and metastatic potential [72]. A recent study identified differential protein profiles between $\operatorname{ER} \alpha(+)$ and $\operatorname{ER} \alpha(-)$ cells microdissected from the same duct [3]. This study showed that $\mathrm{ER} \alpha(-)$ cells express lower levels of: (1) superoxide dismutase, a protein that plays a key anti-oxidant role in the cell by converting superoxide radical to hydrogen peroxide and oxygen [73]; (2) RalA binding protein, a Ras-related small GTPase that plays a major role in intracellular membrane trafficking, as well as tumorigenesis, invasion, and metastasis [74,75]; (3) galectin-1, a protein that induces apoptosis in breast cancer cells by blocking the cell cycle at the S/G2 transition [76]; (4) uridine phosphorylase 2, a protein that catalyzes the phosphorolysis of uridine to uracil and is involved in fluoropyrimidine metabolism, playing a role in the intracellular activation of 5-fluorouracil [77]; (5) cellular retinoic acid-binding protein 1 which regulates retinoic acid activity by increasing its degradation rate by enhancing the production of RA metabolizing enzymes [78]; (6) S100 calcium binding protein A11, involved in tumorigenesis [79], although it has been shown to be upregulated in some cancers [80]; and (7) nucleoside diphosphate kinase A or non-metastasis protein 23-H1 (nm23-H1), a metastasis suppressor gene in which restoration reduces metastasis of breast cancer $[81,82]$. ER $\alpha(-)$ microdissected cells expressed higher levels of Rho GDP-dissociation inhibitor 1 alpha, a cellular protein that controls the cellular distribution and activity of Rho GTPases and reported to promote the resistance of cancer cells to drug-induced toxicity, thus playing an anti-apoptotic role [83-85]. The collective role of the alterations of protein expression in ER $\alpha(-)$ cells may be to promote a more malignant phenotype than adjacent $\operatorname{ER} \alpha(+)$ cells, including a decreased ability to undergo apoptosis and differentiation and an increased potential to damage DNA, metastasize, and resist chemotherapy. A percentage of ER $\alpha(-)$ breast cancer cells are composed of breast cancer stem cells, the most aggressive type of breast cancer where treatment requires either inhibition of Notch signaling [86] or treatment with the telomerase inhibitor Imetelstat [87]. These putative biomarkers are summarized in Table 1. 
Table 1. Putative estrogen receptor related breast cancer biomarkers.

\begin{tabular}{lccll}
\hline Putative Biomarkers & ERa(+) & ER $\alpha(-)$ & Function & References \\
\hline 611-CTF & - & + & Resistance to treatment & {$[59]$} \\
FKBPL & + & - & Regulation of ER expression & {$[61]$} \\
BP1 & - & + & Cell proliferation & {$[72]$} \\
Superoxide Dismutase & + & - & Anti-oxidant & {$[73]$} \\
Ral A Binding Protein & + & - & Tumorigenesis-Metastasis & {$[74-75]$} \\
Galectin-1 & + & - & Apoptosis & {$[76]$} \\
Uridine Phosphorylase 2 & + & - & Contributes to drug efficacy & {$[77]$} \\
Cellular retionic acid-binding protein 1 & + & - & Cell growth and differentiation & {$[78]$} \\
Protein S100-A11 & + & - & Tumorigenesis & {$[79]$} \\
Nucleoside Diphosphate Kinase A & + & - & Metastasis suppressor & {$[81-82]$} \\
Rho GDP-Dissociation inhibitor 1 & - & + & Resistance to drugs & {$[83-85]$} \\
\hline
\end{tabular}

\section{Putative Breast Cancer Stem Cell ER $\alpha(-)$ Biomarkers}

Differentiation is an ongoing process in the human mammary gland, culminating during pregnancy and lactation when numerous lobulo-acinar structures containing milk-secreting alveolar cells are formed through extensive proliferation [88]. The cessation of lactation is accompanied by massive apoptosis and tissue remodeling as the gland reverts to a structure resembling that prior to pregnancy. These processes, which may recur multiple times, require a group of cells with high proliferative potential and differentiation ability, a description that fits the definition of stem cells or early progenitor cells [89]. It has been reported that a functional mammary gland is formed by a single cell and a mutated stem cell could be the common cellular origin of teratocarcinomas and epithelial cancers [90,91]. Electron microscopy studies of rodent mammary epithelium indicate that stem cells are relatively undistinguished "small light cells" that occupy an intermediate position between the ductal lumen and basement membrane [92]. Adult stem cells are slow-dividing, long-lived cells that by their very nature are exposed to damaging agents for long periods of time, resulting in the accumulation of mutations that might eventually lead to their transformation [93]. Stem cell migration is regulated by specific chemokines and their receptors [94], and one of these receptors, CXCR4, was found to be overexpressed in metastatic breast cancer [95], leading to the conclusion that tumorigenic stem cells are not only the origin of primary tumors, but might also be responsible for metastases as the result of tumor cell homing and growth at sites removed from the parent tumor $[88,96]$. An additional study revealed that human mammary luminal epithelial cells contain the progenitors of myoepithelial cells [97], and therefore, the focal disruptions in myoepithelial cell layers observed in conjunction with DCIS may be the result of a halt in the differentiation of cancerous luminal stem cells, which then fail to form epithelial and myoepithelial cells.

Comparisons of the proteins extracted from normal or cancerous breast tissues are limited by the fact that breast tissues are composed of heterogeneous cell types. The identification of novel markers for human breast cancer stem cells (comprising approximately $2 \%$ of the total cells) requires their separation from the rest of the cells (the remaining 98\%) contained in vivo. It is believed that breast cancer is functionally heterogeneous and that a rare human breast cancer initiating cell (BrCa-IC) is the only cell type capable of establishing human breast cancer after transplant into NOD/SCID mice [93,98]. 
To find luminal breast stem cell markers, complementary studies have been performed indicating that human breast epithelial stem cells are also located at this intermediate position, and can be characterized by the presence of cytosolic markers such as cytokeratin 19 and cell surface proteins such as epithelial specific antigen (ESA) and stem cell antigen-1 (Sca-1), in addition to the absence of sialomucins (MUC) [99-101]. Four cell surface markers, adhesion molecules CD44 and CD24, the breast/ovarian cancer-specific marker B38.1, and ESA, as well as lineage markers $\left(\operatorname{Lin}^{+}\right)$for hematopoietic, endothelial, mesothelial, and fibroblast cells, have been used to identify and characterize putative human breast cancer stem cells. Only $\mathrm{Lin}^{-} / \mathrm{ESA}^{+} / \mathrm{CD} 44^{+} / \mathrm{CD} 24^{-/ \mathrm{low}} / \mathrm{B} 38.1^{+}$cells generated breast tumors in immunocompromised female mice [102]. Embryonic stem cell marker SOX2 is expressed in early stage breast carcinoma [103]. Breast cancer stem cells were also found to express IL-4, IL-10, and TGF- $\beta 1$ and upregulate the expression of regulatory molecules on T cells.

\section{Promising Cytoskeleton Candidates}

Structural protein differences between $\operatorname{ER} \alpha(+)$ and $\operatorname{ER} \alpha(-)$ breast cancer have not been addressed adequately. Here we identify a few promising structural proteins that need to be analyzed to understand the differences in microtubule dynamics between these two types of breast cancer. Microtubule-targeting drugs (MTTD) used to treat breast cancer exercise their anti-mitotic activities by suppressing microtubule dynamics. They are classified into two categories: the first is composed of vinca alkaloids (Vincristine, Vinblastine, etc.), which are $\beta$-tubulin-binding, microtubule-destabilizing small molecules; and the second is composed of taxanes (Taxol and Docetaxel), which are also $\beta$-tubulin-binding, but stabilize microtubules. Many nuclear movements are microtubule-dependent and the cytoskeleton plays a major role in breaking cell symmetry along Microtubules-Associated Proteins (MAPS) and histones [104-107]. The mechanism of nuclear movement to reorient the centrosome in migrating fibroblasts has recently been identified [108]. A model for cleavage plane geometry during mitosis has also been identified [109]. Acting as anchors for nesprin-2G-SUN2 TAN lines, A-type lamins allow productive movement and proper positioning of the nucleus by actin [110]. A recently identified pathway where actin filaments, promoted by VASP, grow transiently from barbed ends [111] and then undergo a catastrophic burst of disassembly is worth investigating in ER $\alpha(+)$ versus $\mathrm{ER} \alpha(-)$ breast cancer cells [112].

A mechanism of organelle inheritance during mitosis, important in breast cancer, has recently been identified [113]. Along with GRASP Grh1 [114] and BLOC-1, -2, and -3 [115,116], tubulins play a role in organelle biogenesis and modifications to this family of proteins play a major role in directing intracellular trafficking [117,118], microtubule dynamics [119], microtentacle formation [120], epithelial-to-mesenchymal transition [121], and mitotic events [122,123]. FG domains present in tubulin- $\alpha 8$ form a tubular gate structure, or transporter, at the nuclear pore complex center featuring two separate mechanisms directing trafficking [124,125]. The mitochondrial membrane tubulation activity of OPA1 that is suppressed by GTP $\gamma \mathrm{S}$ needs to be analyzed in ER $\alpha(+)$ and ER $\alpha(-)$ breast cancer cells [126-128].

Core microtubule-binding complexes at the kinetochore play a major role in coupling force generation to microtubule plus-end polymerization and depolymerization [129-131]. Formins have recently been recognized as prominent regulators of the microtubule (MT) cytoskeleton where they 
modulate the dynamics of selected MTs during interphase and mitosis [132]. The $9+2$ axoneme, a microtubule-based machine that powers the oscillatory beating of cilia and flagella, and intraflagellar transport machinery is required for cilia assembly [133,134]. Kinetochore-microtubule dynamics regulate mitotic progression [135,136] and avoid chromosomal missegregations that may lead to aneuploidy, an important phenomenon in breast cancer [137,138]. The level of phostensin, undetectable in metastatic breast cancer, is also good candidate [139]. Nup107-160 complex and gamma-TuRC regulate microtubule polymerization at kinetochores [140]. Mitotic kinesin CENP-E promotes microtubule plus-end elongation and utilizes non-motor microtubule binding sites to tune its microtubule attachment dynamics, enabling it to efficiently align and sort microtubules during metaphase spindle assembly and function [141-143]. Proper organization of microtubule minus-ends is needed for midzone stability, cytokinesis [144], and chromosome segregation [145]. Nucleoporins play a role in early mitotic progression and insure that daughter cells are generated only when fully formed NPCs are present [146,147]. The perinucleolar compartment that forms in cancer cells is highly enriched with a subset of recently characterized polymerase III RNAs and RNA-binding proteins $[148,149]$. Diseases of the nuclear envelope also need to be analyzed in $\operatorname{ER} \alpha(+)$ and $\operatorname{ER} \alpha(-)$ breast cancer cells [150]. Non-muscle myosin II plays essential roles in embryonic and post-embryonic development [151]. MyoII and IQGAP/cortexillin play key roles in spatially and temporally regulating leading-edge activity, and RasC activity and the spatiotemporal activation of TORC2 are tightly controlled at the leading edge of chemotaxing cells [152-154]. Vinculin also plays a role in physiological processes such as cell motility, migration, development, and wound healing and loss of this protein has been associated with cancer phenotypes [155], making it another factor that needs to be addressed in $\mathrm{ER} \alpha(+)$ and $\mathrm{ER} \alpha(-)$ breast cancer. A telomere maintenance mechanism has also been described [156]. A recent finding shows that Rap1 is sufficient to suppress most of the telomere aberrations [157], yet these aberrations in $\operatorname{ER} \alpha(+)$ and $\operatorname{ER} \alpha(-)$ breast cancer cells have not been addressed. The list of cytoskeleton candidates are summarized in Table 2.

Table 2. Promising cytoskeleton protein candidates.

\begin{tabular}{lll}
\hline Protein Candidate & Function & References \\
\hline A-type lamins & Proper Positioning of the Nucleus & {$[110]$} \\
VASP & Actin Filament Growth & {$[111]$} \\
GRASP Grh1 & Organelle Biogenesis & {$[114]$} \\
BLOC-1, -2, and -3 & Organelle Biogenesis & {$[115-116]$} \\
OPA1 & Mitochondrial Tubulation & {$[126-128]$} \\
Formins & Microtubule Regulator & {$[132]$} \\
Nup107-160 & Microtubule Polymerization & {$[140]$} \\
gamma-TuRC & Microtubule Polymerization & {$[140]$} \\
CENP-E & Spindle Assembly & {$[141-143]$} \\
Nucleoporins & Mitotic Progression & {$[146-147]$} \\
Vinculin & Cell Motility & {$[155]$} \\
Rap1 & Suppression of Telomere Aberrations & {$[157]$} \\
\hline
\end{tabular}




\section{Conclusions}

Estrogen receptors $\alpha$ and $\beta$, among other estrogen receptors [158], play a major role in the development of mammary glands. $\operatorname{ER} \alpha(-)$ breast cancer remains one of the most therapy-resistant diseases with $\mathrm{ER} \alpha(-)$ cancer cells expressing fewer proteins than their $\mathrm{ER} \alpha(+)$ counterparts. Cancer stem cells, a minor population of $\mathrm{ER} \alpha(-)$ breast tumor cells, retain the stem cell property of self-renewal. Targeting $\operatorname{ER} \alpha(-)$ and breast cancer stem cells is necessary to improve $\operatorname{ER} \alpha(-)$ breast cancer outcome. Microtubule-targeting drugs have been successful in treating breast cancer despite their lack of cancer specificity. Cytoskeleton candidates that are specific to $\operatorname{ER} \alpha(-)$ breast cancer and breast cancer stem cells also need to be identified for future targeting. Cytoskeleton proteins involved in organelle biogenesis, mitosis, perinuclear development, and telomere aberrations need to be analyzed and differences between proteins expressed by $\operatorname{ER} \alpha(+)$ and $\operatorname{ER} \alpha(-)$ need to be identified in order to specifically target $\mathrm{ER} \alpha(-)$ breast cancer.

\section{Acknowledgments}

This work was supported in part by a grant from Charles and Mary Latham Fund to ZJ Sahab, grant BCTR0504465 from the Susan G. Komen Breast Cancer Foundation, grants from the Florida Breast Cancer Coalition Research Foundation, the Elsa U. Pardee Foundation, and the Florida State University to Q-X Sang, grants R01CA129813 and P01 CA130821 to SW Byers, DAMD17-01-1-0129, DAMD17-01-1-0130, PC051308 from the Congressionally Directed Medical Research Programs, BCTR0706983 from The Susan G. Komen Breast Cancer Foundation, 2006CB910505 from the Ministry of Chinese Science and Technology Department, and 2008-02 from the US Military Cancer Institute and Henry M. Jackson Foundation to Yan-Gao Man. The authors thank Mark Druen Roycik at Sang's laboratory for scientific editing of this manuscript.

\section{References}

1. Hanahan, D.; Weinberg, R.A. The hallmarks of cancer. Cell 2000, 100, 57-70.

2. Wiesner, A. Detection of tumor markers with ProteinChip(R) technology. Curr. Pharm. Biotechnol. 2004, 5, 45-67.

3. Sahab, Z.J.; Man, Y.G.; Semaan, S.M.; Newcomer, R.G.; Byers, S.W.; Sang, Q.X.A. Alteration in protein expression in estrogen receptor alpha-negative human breast cancer tissues indicates a malignant and metastatic phenotype. Clin. Exp. Metastasis 2010, 27, 493-503.

4. Wulfkuhle, J.D.; Sgroi, D.C.; Krutzsch, H.; McLean, K.; McGarvey, K.; Knowlton, M.; Chen, S.; Shu, H.J.; Sahin, A.; Kurek, R.; et al. Proteomics of human breast ductal carcinoma in situ. Cancer Res. 2002, 62, 6740-6749.

5. Hsiao, Y.S.; Chou, M.C.; Fowler, C.; Mason, J.T.; Man, Y.G. Breast cancer heterogeneity: Mechanisms, proofs, and implications. J. Cancer 2010, 1, 6-13.

6. Chan, K.; Ng, T.B. Lectin glycoarray technologies for nanoscale biomedical detection. Protein Pept. Lett. 2010, 17, 1417-1425.

7. Choi, S.; Goryll, M.; Sin, L.Y.M.; Wong, P.K.; Chae, J. Microfluidic-based biosensors toward point-of-care detection of nucleic acids and proteins. Microfluid. Nanofluid. 2011, 10, 231-247. 
8. Gemeiner, P.; Mislovicova, D.; Tkac, J.; Svitel, J.; Patoprsty, V.; Hrabarova, E.; Kogan, G.; Kozar, T. Lectinomics II. A highway to biomedical/clinical diagnostics. Biotechnol. Adv. 2009, $27,1-15$.

9. Liu, X.; Dai, Q.; Austin, L.; Coutts, J.; Huo, Q. Gold nanoparticle bioconjugates for biomolecular imaging and detection. Nanotech 2008, 2, 256-258.

10. Liu, X.; Huo, Q. A washing-free and amplification-free one-step homogeneous assay for protein detection using gold nanoparticle probes and dynamic light scattering. J. Immunol. Methods 2009, 349, 38-44.

11. Liu, X.; Dai, Q.; Austin, L.; Coutts, J.; Knowles, G.; Zou, J.H.; Chen, H.; Huo, Q. A one-step homogeneous immunoassay for cancer biomarker detection using gold nanoparticle probes coupled with dynamic light scattering. J. Am. Chem. Soc. 2008, 130, 2780-2782.

12. Marco-Ramell, A.; Bassols, A. Enrichment of low-abundance proteins from bovine and porcine serum samples for proteomic studies. Res. Vet. Sci. 2010, 89, 340-343.

13. Nissum, M.; Foucher, A.L. Analysis of human plasma proteins: A focus on sample collection and separation using free-flow electrophoresis. Expert Rev. Proteomics 2008, 5, 571-587.

14. Pujia, A.; De Angelis, F.; Scumaci, D.; Gaspari, M.; Liberale, C.; Candeloro, P.; Cuda, G.; Di Fabrizio, E. Highly efficient human serum filtration with water-soluble nanoporous nanoparticles. Int. J. Nanomed. 2010, 5, 1005-1015.

15. Shen, H.; Li, X.; Bieberich, C.; Frey, D.D. Serial displacement chromatofocusing and its applications in multidimensional chromatography and gel electrophoresis: II. Experimental results. J. Chromatogr. A 2009, 1216, 977-984.

16. Stempfer, R.; Kubicek, M.; Lang, I.M.; Christa, N.; Gerner, C. Quantitative assessment of human serum high-abundance protein depletion. Electrophoresis 2008, 29, 4316-4323.

17. Xu, X.; Veenstra, T.D. Analysis of biofluids for biomarker research. Proteomics Clin. Appl. 2008, 2, 1403-1412.

18. Sahab, Z.J.; Semaan, S.M.; Sang, Q.X.A. Methodology and applications of disease biomarker identification in human serum. Biomarker Insights 2007, 2, 21-43.

19. Sahab, Z.J.; Suh, Y.; Sang, Q.X.A. Isoelectric point-based prefractionation of proteins from crude biological samples prior to two-dimensional gel electrophoresis. J. Proteome Res. 2005, 4, 2266-2272.

20. Sahab, Z.J.; Iczkowski, K.A.; Sang, Q.X.A. Anion exchange fractionation of serum proteins versus albumin elimination. Anal. Biochem. 2007, 368, 24-32.

21. Wu, H.; Huo, Q.S.; Varnum, S.; Wang, J.; Liu, G.G.; Nie, Z.M.; Liu, J.; Lin, Y.H. Dye-doped silica nanoparticle labels/protein microarray for detection of protein biomarkers. Analyst 2008, $133,1550-1555$.

22. Gustafsson, J.A. Estrogen receptor beta-A new dimension in estrogen mechanism of action. J. Endocrinol. 1999, 163, 379-383.

23. Green, S.; Walter, P.; Kumar, V.; Krust, A.; Bornert, J.M.; Argos, P.; Chambon, P. Human estrogen-receptor Cdna-Sequence, expression and homology to V-Erb-A. Nature 1986, 320, 134-139.

24. Greene, G.L.; Gilna, P.; Waterfield, M.; Baker, A.; Hort, Y.; Shine, J. Sequence and expression of human estrogen-receptor complementary-DNA. Science 1986, 231, 1150-1154. 
25. Kuiper, G.; Enmark, E.; PeltoHuikko, M.; Nilsson, S.; Gustafsson, J.A. Cloning of a novel estrogen receptor expressed in rat prostate and ovary. Proc. Natl. Acad. Sci. USA 1996, 93, 5925-5930.

26. Mosselman, S.; Polman, J.; Dijkema, R. ER beta: Identification and characterization of a novel human estrogen receptor. FEBS Lett. 1996, 392, 49-53.

27. Tong, D.; Schuster, E.; Seifert, M.; Czerwenka, K.; Leodolter, S.; Zeillinger, R. Expression of estrogen receptor beta isoforms in human breast cancer tissues and cell lines. Breast Cancer Res. Treat. 2002, 71, 249-255.

28. Hall, J.M.; McDonnell, D.P. The estrogen receptor beta-isoform (ER beta) of the human estrogen receptor modulates ER alpha transcriptional activity and is a key regulator of the cellular response to estrogens and antiestrogens. Endocrinology 1999, 140, 5566-5578.

29. Wang, Z.Z.; Li, Y.; Ai, C.Z.; Wang, Y.H. In silico prediction of estrogen receptor subtype binding affinity and selectivity using statistical methods and molecular docking with 2-Arylnaphthalenes and 2-Arylquinolines. Int. J. Mol. Sci. 2010, 11, 3434-3458.

30. Pettersson, K.; Delaunay, F.; Gustafsson, J.A. Estrogen receptor beta acts as a dominant regulator of estrogen signaling. Oncogene 2000, 19, 4970-4978.

31. Paruthiyil, S.; Parmar, H.; Kerekatte, V.; Cunha, G.R.; Firestone, G.L.; Leitman, D.C. Estrogen receptor beta inhibits human breast cancer cell proliferation and tumor formation by causing a G(2) cell cycle arrest. Cancer Res. 2004, 64, 423-428.

32. Couse, J.F.; Korach, K.S. Estrogen receptor null mice: What have we learned and where will they lead us? Endocr. Rev. 1999, 20, 459-459.

33. Bocchinfuso, W.P.; Lindzey, J.K.; Hewitt, S.C.; Clark, J.A.; Myers, P.H.; Cooper, R.; Korach, K.S. Induction of mammary gland development in estrogen receptor-alpha knockout mice. Endocrinology 2000, 141, 2982-2994.

34. Krege, J.H.; Hodgin, J.B.; Couse, J.F.; Enmark, E.; Warner, M.; Mahler, J.F.; Sar, M.; Korach, K.S.; Gustafsson, J.A.; Smithies, O. Generation and reproductive phenotypes of mice lacking estrogen receptor beta. Proc. Natl. Acad. Sci. USA 1998, 95, 15677-15682.

35. An, J.P.; Tzagarakis-Foster, C.; Scharschmidt, T.C.; Lomri, N.; Leitman, D.C. Estrogen receptor beta-selective transcriptional activity and recruitment of coregulators by phytoestrogens. J. Biol. Chem. 2001, 276, 17808-17814.

36. Oesterreich, S.; Zhang, P.; Guler, R.L.; Sun, X.H.; Curran, E.M.; Welshons, W.V.; Osborne, C.K.; Lee, A.V. Re-expression of estrogen receptor alpha in estrogen receptor alpha-negative MCF-7 cells restores both estrogen and insulin-like growth factor-mediated signaling and growth. Cancer Res. 2001, 61, 5771-5777.

37. Liu, M.M.; Albanese, C.; Anderson, C.M.; Hilty, K.; Webb, P.; Uht, R.M.; Price, R.H.; Pestell, R.G.; Kushner, P.J. Opposing action of estrogen receptors alpha and beta on cyclin D1 gene expression. J. Biol. Chem. 2002, 277, 24353-24360.

38. Strom, A.; Hartman, J.; Foster, J.S.; Kietz, S.; Wimalasena, J.; Gustafsson, J.A. Estrogen receptor beta inhibits 17 beta-estradiol-stimulated proliferation of the breast cancer cell line T47D. Proc. Natl. Acad. Sci. USA 2004, 101, 1566-1571.

39. Lazennec, G.; Bresson, D.; Lucas, A.; Chauveau, C.; Vignon, F. ER beta inhibits proliferation and invasion of breast cancer cells. Endocrinology 2001, 142, 4120-4130. 
40. Skliris, G.P.; Munot, K.; Bell, S.M.; Carder, P.J.; Lane, S.; Horgan, K.; Lansdown, M.R.J.; Parkes, A.T.; Hanby, A.M.; Markham, A.F.; et al. Reduced expression of oestrogen receptor beta in invasive breast cancer and its re-expression using DNA methyl transferase inhibitors in a cell line model. J. Pathol. 2003, 201, 213-220.

41. Roger, P.; Sahla, M.E.; Makela, S.; Gustafsson, J.A.; Baldet, P.; Rochefort, H. Decreased expression of estrogen receptor beta protein in proliferative preinvasive mammary tumors. Cancer Res. 2001, 61, 2537-2541.

42. Park, B.W.; Kim, K.S.; Heo, M.K.; Ko, S.S.; Hong, S.W.; Yang, W.I.; Kim, J.H.; Kim, G.E.; Lee, K.S. Expression of estrogen receptor-beta in normal mammary and tumor tissues: Is it protective in breast carcinogenesis? Breast Cancer Res. Treat. 2003, 80, 79-85.

43. Man, Y.G.; Tai, L.; Barner, R.; Vang, R.; Saenger, J.S.; Shekitka, K.M.; Bratthauer, G.L.; Wheeler, D.T.; Liang, C.Y.; Vinh, T.N.; Strauss, B.L. Cell clusters overlying focally disrupted mammary myoepithelial cell layers and adjacent cells within the same duct display different immunohistochemical and genetic features: Implications for tumor progression and invasion. Breast Cancer Res. 2003, 5, R231-R241.

44. Al-Hajj, M.; Clarke, M.F. Self-renewal and solid tumor stem cells. Oncogene 2004, 23, 7274-7282.

45. Al-Hajj, M.; Becker, M.W.; Wichal, M.; Weissman, I.; Clarke, M.F. Therapeutic implications of cancer stem cells. Curr. Opin. Genet. Dev. 2004, 14, 43-47.

46. Munzone, E.; Curigliano, G.; Rocca, A.; Bonizzi, G.; Renne, G.; Goldhirsch, A.; Nole, F. Reverting estrogen-receptor-negative phenotype in HER-2-overexpressing advanced breast cancer patients exposed to trastuzumab plus chemotherapy. Breast Cancer Res. 2006, 8, R4:1-R4:4.

47. Clarke, R.B.; Spence, K.; Anderson, E.; Howell, A.; Okano, H.; Potten, C.S. A putative human breast stem cell population is enriched for steroid receptor-positive cells. Dev. Biol. 2005, 277, 443-456.

48. Man, Y.G. Aberrant leukocyte infiltration: A direct trigger for breast tumor invasion and metastasis. Int. J. Biol. Sci. 2010, 6, 129-132.

49. Man, Y.G. Tumor cell budding from focally disrupted tumor capsules: A common pathway for all breast cancer subtype derived invasion? J. Cancer 2010, 1, 32-37.

50. Man, Y.G.; Mason, J.; Vinh, T.N.; Zhang, S.M.; Stamatakos, M.D. Focal myoepithelial cell layer disruptions and basement membrane disappearance are correlated events: Implications for breast tumor invasion. FASEB J. 2007, 21, A386-A386.

51. Man, Y.G.; Sang, Q.X.A. The significance of focal myoepithelial cell layer disruptions in human breast tumor invasion: A paradigm shift from the "protease-centered" hypothesis. Exp. Cell Res. 2004, 301, 103-118.

52. Man, Y.G.; Shekitka, K.M.; Bratthauer, G.L.; Tavassoli, F.A. Immunohistochemical and genetic alterations in mammary epithelial cells immediately overlying focally disrupted myoepithelial cell layers. Breast Cancer Res. Treat. 2002, 76, S143.

53. Man, Y.G.; Shen, T.; Weisz, J.; Berg, P.E.; Schwartz, A.M.; Mulshine, J.L.; Sang, Q.X.; Nieburgs, H.E. A subset of in situ breast tumor cell clusters lacks expression of proliferation and progression related markers but shows signs of stromal and vascular invasion. Cancer Detect. Prev. 2005, 29, 323-331. 
54. Man, Y.G.; Zhang, Y.; Shen, T.; Zeng, X.; Tauler, J.; Mulshine, J.L.; Strauss, B.L. cDNA expression profiling reveals elevated gene expression in cell clusters overlying focally disrupted myoepithelial cell layers: Implications for breast tumor invasion. Breast Cancer Res. Treat. 2005, 89, 199-208.

55. Zhang, C.L.; Mori, M.; Gao, S.L.; Li, A.M.; Hoshino, I.; Aupperlee, M.D.; Haslam, S.Z.; Xiao, H. Tip30 deletion in MMTV-Neu mice leads to enhanced EGFR signaling and development of estrogen receptor-positive and progesterone receptor-negative mammary tumors. Cancer Res. 2010, 70, 10224-10233.

56. Simonini, P.D.R.; Breiling, A.; Gupta, N.; Malekpour, M.; Youns, M.; Omranipour, R.; Malekpour, F.; Volinia, S.; Croce, C.M.; Najmabadi, H.; et al. Epigenetically deregulated microRNA-375 is involved in a positive feedback loop with estrogen receptor alpha in breast cancer cells. Cancer Res. 2010, 70, 9175-9184.

57. Yang, J.; Jubb, A.M.; Pike, L.; Buffa, F.M.; Turley, H.; Baban, D.; Leek, R.; Gatter, K.C.; Ragoussis, J.; Harris, A.L. The Histone demethylase JMJD2B is regulated by estrogen receptor alpha and hypoxia, and is a key mediator of estrogen induced growth. Cancer Res. 2010, 70, 6456-6466.

58. Li, L.; Lu, Y. Inhibition of hypoxia-induced cell motility by p16 in MDA-MB-231 breast cancer cells. J. Cancer 2010, 1, 126-135.

59. Parra-Palau, J.L.; Pedersen, K.; Peg, V.; Scaltriti, M.; Angelini, P.D.; Escorihuela, M.; Mancilla, S.; Pla, A.S.; Cajal, S.R.Y.; Baselga, J.; et al. A major role of p95/611-CTF, a carboxy-terminal fragment of HER2, in the down-modulation of the estrogen receptor in HER2-Positive breast cancers. Cancer Res. 2010, 70, 8537-8546.

60. Diaz-Cruz, E.S.; Furth, P.A. Deregulated estrogen receptor alpha and p53 heterozygosity collaborate in the development of mammary hyperplasia. Cancer Res. 2010, 70, 3965-3974.

61. McKeen, H.D.; Byrne, C.; Jithesh, P.V.; Donley, C.; Valentine, A.; Yakkundi, A.; O'Rourke, M.; Swanton, C.; McCarthy, H.O.; Hirst, D.G.; et al. FKBPL regulates estrogen receptor signaling and determines response to endocrine therapy. Cancer Res. 2010, 70, 1090-1100.

62. Ronneberg, J. A.; Fleischer, T.; Solvang, H. K.; Nordgard, S. H.; Edvardsen, H.; Potapenko, I.; Nebdal, D.; Daviaud, C.; Gut, I.; Bukholm, I.; et al. Methylation profiling with a panel of cancer related genes: Association with estrogen receptor, TP53 mutation status and expression subtypes in sporadic breast cancer. Mol. Oncol. 2011, 5, 61-76.

63. Rhodes, L.V.; Short, S.P.; Neel, N.F.; Salvo, V.A.; Zhu, Y.; Elliott, S.; Wei, Y.K.; Yu, D.H.; Sun, M.H.; Muir, S.E.; et al. Cytokine receptor CXCR4 mediates estrogen-independent tumorigenesis, metastasis, and resistance to endocrine therapy in human breast cancer. Cancer Res. 2011, 71, 603-613.

64. Duangmano, S.; Dakeng, S.; Jiratchariyakul, W.; Suksamrarn, A.; Smith, D.R.; Patmasiriwat, P. Antiproliferative effects of cucurbitacin B in breast cancer cells: Down-regulation of the c-Myc/hTERT/Telomerase pathway and obstruction of the cell cycle. Int. J. Mol. Sci. 2010, 11, 5323-5338.

65. Shukla, V.; Coumoul, X.; Lahusen, T.; Wang, R.H.; Xu, X.L.; Vassilopoulos, A.; Xiao, C.Y.; Lee, M.H.; Man, Y.G.; Ouchi, M.; et al. BRCA1 affects global DNA methylation through regulation of DNMT1. Cell Res. 2010, 20, 1201-1215. 
66. Hsiao, Y.H.; Su, Y.A.; Tsai, H.D.; Mason, J.T.; Chou, M.C.; Man, Y.G. Increased invasiveness and aggressiveness in breast epithelia with cytoplasmic p63 expression. Int. J. Biol. Sci. 2010, 6, 428-442.

67. Man, Y.G.; Harley, R.; Mason, J.; Gardner, W.A. Contributions of leukocytes to tumor invasion and metastasis: The "piggy-back" hypothesis. Cancer Epidemiol. 2010, 34, 3-6.

68. Kluk, B.J.; Fu, Y.B.; Formolo, T.A.; Zhang, L.; Hindle, A.K.; Man, Y.G.; Siegel, R.S.; Berg, P.E.; Deng, C.X.; McCaffrey, T.A.; Fu, S.W. BP1, an isoform of DLX4 homeoprotein, negatively regulates BRCA1 in sporadic breast cancer. Int. J. Biol. Sci. 2010, 6, 513-524.

69. O’Brien, J.; Lyons, T.; Monks, J.; Lucia, M.S.; Wilson, R.S.; Hines, L.; Man, Y.G.; Borges, V.; Schedin, P. Alternatively activated macrophages and collagen remodeling characterize the postpartum involuting mammary gland across species. Am. J. Pathol. 2010, 176, 1241-1255.

70. Sahab, Z.J.; Hall, M.D.; Sung, Y.M.; Dakshanamurthy, S.; Ji, Y.; Kumar, D.; Byers, S.W. Tumor suppressor RARRES1 interacts with cytoplasmic carboxypeptidase AGBL2 to regulate the a-tubulin tyrosination cycle. Cancer Res. 2011, 71, 1219-1228.

71. Sahab, Z.J.; Hall, M.D.; Zhang, L.; Cheema, A.; Byers, S.W. Tumor suppressor RARRES1 regulates DLG2, PP2A, VCP, EB1, and Ankrd26. J. Cancer 2010, 1, 14-22.

72. Fu, Y.; Lian, Y.; Kim, K.S.; Zhang, L.; Hindle, A.K. Brody, F.; Siegel, R.S.; McCaffrey, T.A.; SW., F. BP1 homeoprotein enhances metastatic potential in er-negative breast cancer. J. Cancer 2010, 1, 54-62.

73. Briehl, M.M.; Baker, A.F.; Siemankowski, L.M.; Morreale, J. Modulation of antioxidant defenses during apoptosis. Oncol. Res. 1997, 9, 281-285.

74. Tchevkina, E.; Agapova, L.; Dyakova, N.; Martinjuk, A.; Komelkov, A.; Tatosyan, A. The small G-protein RalA stimulates metastasis of transformed cells. Oncogene 2005, 24, 329-335.

75. Ward, Y.; Wang, W.; Woodhouse, E.; Linnoila, I.; Liotta, L.; Kelly, K. Signal pathways which promote invasion and metastasis: Critical and distinct contributions of extracellular signal-regulated kinase and Ral-specific guanine exchange factor pathways. Mol. Cell. Biol. 2001, 21, 5958-5969.

76. Wells, V.; Davies, D.; Mallucci, L. Cell cycle arrest and induction of apoptosis by beta galactoside binding protein (beta GBP) in human mammary cancer cells. A potential new approach to cancer control. Eur. J. Cancer 1999, 35, 978-983.

77. Cao, D.L.; Russell, R.L.; Zhang, D.K.; Leffert, J.J.; Pizzorno, G. Uridine phosphorylase (-/-) murine embryonic stem cells clarify the key role of this enzyme in the regulation of the pyrimidine salvage pathway and in the activation of fluoropyrimidines. Cancer Res. 2002, 62, 2313-2317.

78. Dong, D.; Ruuska, S.E.; Levinthal, D.J.; Noy, N. Distinct roles for cellular retinoic acid-binding proteins I and II in regulating signaling by retinoic acid. J. Biol. Chem. 1999, 274, 23695-23698.

79. Kondo, A.; Sakaguchi, M.; Makino, E.; Namba, M.; Okada, S.; Huh, N.H. Localization of S100C immunoreactivity in various human tissues. Acta Med. Okayama 2002, 56, 31-34.

80. Oue, N.; Hamai, Y.; Mitani, Y.; Matsumura, S.; Oshimo, Y.; Aung, P.P.; Kuraoka, K.; Nakayama, H.; Yasui, W. Gene expression profile of gastric carcinoma: Identification of genes and tags potentially involved in invasion, metastasis, and carcinogenesis by serial analysis of gene expression. Cancer Res. 2004, 64, 2397-2405. 
81. Steeg, P.S.; Bevilacqua, G.; Kopper, L.; Thorgeirsson, U.P.; Talmadge, J.E.; Liotta, L.A.; Sobel, M.E. Evidence for a novel gene associated with low tumor metastatic potential. J. Natl. Cancer Inst. 1988, 80, 200-204.

82. Leone, A.; Flatow, U.; King, C.R.; Sandeen, M.A.; Margulies, I.M.K.; Liotta, L.A.; Steeg, P.S. Reduced tumor-incidence, metastatic potential, and cytokine responsiveness of Nm23-transfected melanoma-cells. Cell 1991, 65, 25-35.

83. Zhang, B.L.; Zhang, Y.Q.; Dagher, M.C.; Shacter, E. Rho GDP dissociation inhibitor protects cancer cells against drug-induced apoptosis. Cancer Res. 2005, 65, 6054-6062.

84. Sasaki, T.; Takai, Y. The Rho small G protein family Rho GDI system as a temporal and spatial determinant for cytoskeletal control. Biochem. Biophys. Res. Commun. 1998, 245, 641-645.

85. Olofsson, B. Rho guanine dissociation inhibitors: Pivotal molecules in cellular signalling. Cell Signal. 1999, 11, 545-554.

86. Grudzien, P.; Lo, S.; Albain, K.S.; Robinson, P.; Rajan, P.; Strack, P.R.; Golde, T.E.; Miele, L.; Foreman, K.E. Inhibition of notch signaling reduces the stem-like population of breast cancer cells and prevents mammosphere formation. Anticancer Res. 2010, 30, 3853-3867.

87. Joseph, I.; Tressler, R.; Bassett, E.; Harley, C.; Buseman, C.M.; Pattamatta, P.; Wright, W.E.; Shay, J.W.; Go, N.F. the telomerase inhibitor imetelstat depletes cancer stem cells in breast and pancreatic cancer cell lines. Cancer Res. 2010, 70, 9494-9504.

88. Dontu, G.; Al-Hajj, M.; Abdallah, W.A.; Clarke, M.F.; Wicha, M.S. Stem cells in normal breast development and breast cancer. Cell Prolif. 2003, 36, 59-72.

89. Dontu, G.; Ginestier, C.; Jauffret, E.; Wicha, M. Breast cancer stem cells: Biological and clinical implications. Tumor Biol. 2007, 28, 54-54.

90. Sell, S.; Pierce, G.B. Maturation arrest of stem-cell differentiation is a common pathway for the cellular-origin of teratocarcinomas and epithelial cancers. Lab. Invest. 1994, 70, 6-22.

91. Kordon, E.C.; Smith, G.H. An entire functional mammary gland may comprise the progeny from a single cell. Development 1998, 125, 1921-1930.

92. Chepko, G.; Smith, G.H. Three division-competent, structurally-distinct cell populations contribute to murine mammary epithelial renewal. Tissue Cell 1997, 29, 239-253.

93. Dick, J.E. Breast cancer stem cells revealed. Proc. Natl. Acad. Sci. USA 2003, 100, 3547-3549.

94. Peled, A.; Petit, I.; Kollet, O.; Magid, M.; Ponomaryov, T.; Byk, T.; Nagler, A.; Ben-Hur, H.; Many, A.; Shultz, L.; et al. Dependence of human stem cell engraftment and repopulation of NOD/SCID mice on CXCR4. Science 1999, 283, 845-848.

95. Muller, A.; Homey, B.; Soto, H.; Ge, N.F.; Catron, D.; Buchanan, M.E.; McClanahan, T.; Murphy, E.; Yuan, W.; Wagner, S.N.; et al. Involvement of chemokine receptors in breast cancer metastasis. Nature 2001, 410, 50-56.

96. Tu, S.M.; Lin, S.H.; Logothetis, C.J. Stem-cell origin of metastasis and heterogeneity in solid tumours. Lancet Oncol. 2002, 3, 508-513.

97. Pechoux, C.; Gudjonsson, T.; Ronnov-Jessen, L.; Bissell, M.J.; Petersen, O.W. Human mammary luminal epithelial cells contain progenitors to myoepithelial cells. Dev. Biol. 1999, 206, 88-99. 
98. Al-Hajj, M.; Wicha, M.S.; Benito-Hernandez, A.; Morrison, S.J.; Clarke, M.F. Prospective identification of tumorigenic breast cancer cells (vol 100, pg 3983, 2003). Proc. Natl. Acad. Sci. USA 2003, 100, 6890-6890.

99. Stingl, J.; Eaves, C.J., Zandieh, I.; Emerman, J.T. Characterization of bipotent mammary epithelial progenitor cells in normal adult human breast tissue. Breast Cancer Res. Treat. 2001, 67, 93-109.

100. Gudjonsson, T.; Ronnov-Jessen, L.; Villadsen, R.; Rank, F.; Bissell, M.J.; Petersen, O.W. Normal and tumor-derived myoepithelial cells differ in their ability to interact with luminal breast epithelial cells for polarity and basement membrane deposition. J. Cell Sci. 2002, 115, 39-50.

101. Welm, B.E.; Tepera, S.B.; Venezia, T.; Graubert, T.A.; Rosen, J.;M.; Goodell, M.A. Sca-1(pos) cells in the mouse mammary gland represent an enriched progenitor cell population. Dev. Biol. 2002, 245, 42-56.

102. Al-Hajj, M.; Wicha, M.S.; Benito-Hernandez, A.; Morrison, S.J.; Clarke, M.F. Prospective identification of tumorigenic breast cancer cells. Proc. Natl. Acad. Sci. USA 2003, 100, 3983-3988.

103. Lengerke, C.; Fehm, T.; Kurth, R.; Neubauer, H.; Scheble, V.; Muller, F.; Schneider, F.; Petersen, K.; Wallwiener, D.; Kanz, L.; et al. Expression of the embryonic stem cell marker SOX2 in early-stage breast carcinoma. BMC Cancer 2011, 11, 42.

104. Subramanian, R.; Wilson-Kubalek, E.M.; Arthur, C.P.; Bick, M.J.; Campbell, E.A.; Darst, S.A.; Milligan, R.A.; Kapoor, T.M. Insights into antiparallel microtubule crosslinking by PRC1, a conserved nonmotor microtubule binding protein. Cell 2010, 142, 433-443.

105. Walczak, C.E.; Shaw, S.L. A map for bundling microtubules. Cell 2010, 142, 364-367.

106. Li, X.; Kapoor, T.M. Approach to profile proteins that recognize post-translationally modified histone "tails". J. Am. Chem. Soc. 2010, 132, 2504-2505.

107. Mullins, R.D. Cytoskeletal mechanisms for breaking cellular symmetry. Cold Spring Harbor Perspect. Biol. 2010, 2, a003392.

108. Luxton, G.W.G.; Gomes, E.R.; Folker, E.S.; Vintinner, E.; Gundersen, G.G. Linear arrays of nuclear envelope proteins harness retrograde actin flow for nuclear movement. Science $\mathbf{2 0 1 0}$, 329, 956-959.

109. Wuhr, M.; Tan, E.S.; Parker, S.K.; Detrich, H.W.; Mitchison, T.J. A model for cleavage plane determination in early amphibian and fish embryos. Curr. Biol. 2010, 20, 2040-2045.

110. Folker, E.S.; Ostlund, C.; Luxton, G.W.G.; Worman, H.J.; Gundersen, G.G. Lamin A variants that cause striated muscle disease are defective in anchoring transmembrane actin-associated nuclear lines for nuclear movement. Proc. Natl. Acad. Sci. USA 2011, 108, 131-136.

111. Hansen, S.D.; Mullins, R.D. VASP is a processive actin polymerase that requires monomeric actin for barbed end association. J. Cell Biol. 2010, 191, 571-584.

112. Kueh, H.Y.; Brieher, W.M.; Mitchison, T.J. Quantitative analysis of actin turnover in listeria comet tails: Evidence for catastrophic filament turnover. Biophys. J. 2010, 99, 2153-2162.

113. Jin, Y.; Eves, P.T.; Tang, F.; Weisman, L.S. PTC1 is required for vacuole inheritance and promotes the association of the myosin-v vacuole-specific receptor complex. Mol. Biol. Cell 2009, 20, 1312-1323. 
114. Levi, S.K.; Bhattacharyya, D.; Strack, R.L.; Austin, J.R.; Glick, B.S. The yeast GRASP Grh1 colocalizes with COPII and is dispensable for organizing the secretory pathway. Traffic 2010, 11, 1168-1179.

115. Cheli, V.T.; Daniels, R.W.; Godoy, R.; Hoyle, D.J.; Kandachar, V.; Starcevic, M.; Martinez-Agosto, J.A.; Poole, S.; DiAntonio, A.; Lloyd, V.K.; et al Genetic modifiers of abnormal organelle biogenesis in a Drosophila model of BLOC-1 deficiency. Hum. Mol. Genet. 2010, 19, 861-878.

116. Cheli, V.T.; Dell'Angelica, E.C. Early origin of genes encoding subunits of biogenesis of lysosome-related organelles complex-1, -2 and -3. Traffic 2010, 11, 579-586.

117. Gurland, G.; Gundersen, G.G. Stable, detyrosinated microtubules function to localize vimentin intermediate filaments in fibroblasts. J. Cell Biol. 1995, 131, 1275-1290.

118. Lin, S.X.; Gundersen, G.G.; Maxfield, F.R. Export from pericentriolar endocytic recycling compartment to cell surface depends on stable, detyrosinated (Glu) microtubules and kinesin. Mol. Biol. Cell 2002, 13, 96-109.

119. Tran, A.D.A.; Marmo, T.P.; Salam, A.A.; Che, S.; Finkelstein, E.; Kabarriti, R.; Xenias, H.S.; Mazitschek, R.; Hubbert, C.; Kawaguchi, Y.; et al. HDAC6 deacetylation of tubulin modulates dynamics of cellular adhesions. J. Cell Sci. 2007, 120, 1469-1479.

120. Matrone, M.A.; Whipple, R.A.; Balzer, E.M.; Martin, S.S. Microtentacles tip the balance of cytoskeletal forces in circulating tumor cells. Cancer Res. 2010, 70, 7737-7741.

121. Whipple, R.A.; Matrone, M.A.; Cho, E.H.; Balzer, E.M.; Vitolo, M.I.; Yoon, J.R.; Ioffe, O.B.; Tuttle, K.C.; Yang, J.; Martin, S.S. Epithelial-to-mesenchymal transition promotes tubulin detyrosination and microtentacles that enhance endothelial engagement. Cancer Res. 2010, 70, 8127-8137.

122. Sawin, K.E.; Mitchison, T.J. Mutations in the kinesin-like protein Eg5 disrupting localization to the mitotic spindle. Proc. Natl. Acad. Sci. USA 1995, 92, 4289-4293.

123. Sauer, G.; Korner, R.; Hanisch, A.; Ries, A.; Nigg, E.A.; Sillje, H.H.W. Proteome analysis of the human mitotic spindle. Mol. Cell. Proteomics 2005, 4, 35-43.

124. Yamada, J.; Phillips, J.L.; Patel, S.; Goldfien, G.; Calestagne-Morelli, A.; Huang, H.; Reza, R.; Acheson, J.; Krishnan, V.V.; Newsam, S.; et al. A bimodal distribution of two distinct categories of intrinsically disordered structures with separate functions in FG nucleoporins. Mol. Cell. Proteomics 2010, 9, 2205-2224.

125. Jin, N.; Chow, C.Y.; Liu, L.; Zolov, S.N.; Bronson, R.; Davisson, M.; Petersen, J.L.; Zhang, Y.L.; Park, S.; Duex, J.E.; et al. VAC14 nucleates a protein complex essential for the acute interconversion of PI3P and PI(3,5)P-2 in yeast and mouse. EMBO J. 2008, 27, 3221-3234.

126. Ban, T.; Heymann, J.A.W.; Song, Z.Y.; Hinshaw, J.E.; Chan, D.C. OPA1 disease alleles causing dominant optic atrophy have defects in cardiolipin-stimulated GTP hydrolysis and membrane tubulation. Hum. Mol. Genet. 2010, 19, 2113-2122.

127. Chen, H.C.; Vermulst, M.; Wang, Y.E.; Chomyn, A.; Prolla, T.A.; McCaffery, J.M.; Chan, D.C. Mitochondrial fusion is required for mtdna stability in skeletal muscle and tolerance of mtDNA mutations. Cell 2010, 141, 280-289.

128. Chen, H.C.; Chan, D.C. Mitochondrial dynamics-fusion, fission, movement, and mitophagy-in neurodegenerative diseases. Hum. Mol. Genet. 2009, 18, R169-R176. 
129. Bouck, D.C.; Joglekar, A.P.; Bloom, K.S. Design features of a mitotic spindle: Balancing tension and compression at a single microtubule kinetochore interface in budding yeast. Annu. Rev. Genet. 2008, 42, 335-359.

130. Joglekar, A.P.; Bouck, D.; Finley, K.; Liu, X.K.; Wan, Y.K.; Berman, J.; He, X.W.; Salmon, E.D.; Bloom, K.S. Molecular architecture of the kinetochore-microtubule attachment site is conserved between point and regional centromeres. J. Cell Biol. 2008, 181, 587-594.

131. Joglekar, A.P.; Bloom, K.S.; Salmon, E.D. Mechanisms of force generation by end-on kinetochore-microtubule attachments. Curr. Opin. Cell Biol. 2010, 22, 57-67.

132. Bartolini, F.; Gundersen, G.G. Formins and microtubules. Biochim. Et Biophys. Acta-Mol. Cell Res. 2010, 1803, 164-173.

133. Bayly, P.V.; Lewis, B.L.; Kemp, P.S.; Pless, R.B.; Dutcher, S.K. Efficient spatiotemporal analysis of the flagellar waveform of Chlamydomonas reinhardtii. Cytoskeleton 2010, 67, 56-69.

134. Iomini, C.; Li, L.Y.; Esparza, J.M.; Dutcher, S.K. Retrograde intraflagellar transport mutants identify complex a proteins with multiple genetic interactions in chlamydomonas reinhardtii. Genetics 2009, 183, 885-896.

135. Manning, A.L.; Bakhoum, S.F.; Maffini, S.; Correia-Melo, C.; Maiato, H.; Compton, D.A. CLASP1, astrin and Kif2b form a molecular switch that regulates kinetochore-microtubule dynamics to promote mitotic progression and fidelity. EMBO J. 2010, 29, 3531-3543.

136. Thompson, S.L.; Bakhoum, S.F.; Compton, D.A. Mechanisms of chromosomal instability. Curr. Biol. 2010, 20, R285-R295.

137. Compton, D.A. Mechanisms of aneuploidy. Curr. Opin. Cell Biol. 2011, 23, 109-113.

138. Thompson, S.L.; Compton, D.A. Proliferation of aneuploid human cells is limited by a p53-dependent mechanism. J. Cell Biol. 2010, 188, 369-381.

139. Su, Y.A.; Yang, J.; Tao, L.; Nguyen, H.; He, P. Undetectable and decreased expression of KIAA1949 (Phostensin) encoded on chromosome 6p21.33 in human breast cancers revealed by transcriptome analysis. J. Cancer 2010, 1, 38-50.

140. Mishra, R.K.; Chakraborty, P.; Arnaoutov, A.; Fontoura, B.M.A.; Dasso, M. The Nup107-160 complex and gamma-TuRC regulate microtubule polymerization at kinetochores. Nat. Cell Biol. 2010, 12, 164-169.

141. Weinger, J.S.; Qiu, M.H.; Yang, G.; Kapoor, T.M. A nonmotor microtubule binding site in Kinesin-5 is required for filament crosslinking and sliding. Curr. Biol. 2011, 21, 154-160.

142. Ems-McClung, S.C.; Walczak, C.E. Kinesin-13s in mitosis: Key players in the spatial and temporal organization of spindle microtubules. Semin. Cell Dev. Biol. 2010, 21, 276-282.

143. Sardar, H.S.; Luczak, V.G.; Lopez, M.M.; Lister, B.C.; Gilbert, S.P. Mitotic kinesin CENP-E promotes microtubule plus-end elongation. Curr. Biol. 2010, 20, 1648-1653.

144. Cai, S.; Weaver, L.N.; Ems-McClung, S.C.; Walczak, C.E. Proper organization of microtubule minus ends is needed for midzone stability and cytokinesis. Curr. Biol. 2010, 20, 880-885.

145. Walczak, C.E.; Cai, S.; Khodjakov, A. Mechanisms of chromosome behaviour during mitosis. Nat. Rev. Mol. Cell Biol. 2010, 11, 91-102.

146. Mackay, D.R.; Makise, M.; Ullman, K.S. Defects in nuclear pore assembly lead to activation of an Aurora B-mediated abscission checkpoint. J. Cell Biol. 2010, 191, 923-931. 
147. Mackay, D.R.; Elgort, S.W.; Ullman, K.S. The nucleoporin Nup153 has separable roles in both early mitotic progression and the resolution of mitosis. Mol. Biol. Cell 2009, 20, 1652-1660.

148. Pollock, C.; Daily, K.; Van, T.N.; Wang, C.; Lewandowska, M.A.; Bensaude, O.; Huang, S. Characterization of MRP RNA-protein interactions within the perinucleolar compartment. Mol. Biol. Cell 2011, 22, 858-867.

149. Pollock, C.; Huang, S. The perinucleolar compartment. Cold Spring Harb. Perspect. Biol. 2010, 2, a000679.

150. Worman, H.J.; Ostlund, C.; Wang, Y.X. Diseases of the nuclear envelope. Cold Spring Harb. Perspect. Biol. 2010, 2, a000760.

151. Franke, J.D.; Montague, R.A.; Kiehart, D.P. Nonmuscle myosin II is required for cell proliferation, cell sheet adhesion and wing hair morphology during wing morphogenesis. Dev. Biol. 2010, 345, 117-132.

152. Shin, M.E.; He, Y.A.; Li, D.; Na, S.S.; Chowdhury, F.; Poh, Y.C.; Collin, O.; Su, P.; de Lanerolle, P.; Schwartz, M.A.; et al. Spatiotemporal organization, regulation, and functions of tractions during neutrophil chemotaxis. Blood 2010, 116, 3297-3310.

153. Charest, P.G.; Shen, Z.X.; Lakoduk, A.; Sasaki, A.T.; Briggs, S.P.; Firtel, R.A. A ras signaling complex controls the RasC-TORC2 pathway and directed cell migration. Dev. Cell 2010, 18, 737-749.

154. Lee, S.; Shen, Z.X.; Robinson, D.N.; Briggs, S.; Firtel, R.A. Involvement of the cytoskeleton in controlling leading-edge function during chemotaxis. Mol. Biol. Cell 2010, 21, 1810-1824.

155. Palmer, S.M.; Playford, M.P.; Craig, S.W.; Schaller, M.D.; Campbell, S.L. Lipid binding to the tail domain of vinculin specificity and the role of the $\mathrm{n}$ and c termini. J. Biol. Chem. 2009, 284, 7223-7231.

156. Lue, N.F. Plasticity of telomere maintenance mechanisms in yeast. Trends Biochem. Sci. 2010, $35,8-17$.

157. Yu, E.Y.; Yen, W.F.; Steinberg-Neifach, O.; Lue, N.F. Rap1 in Candida albicans: An unusual structural organization and a critical function in suppressing telomere recombination. Mol. Cell. Biol. 2010, 30, 1254-1268.

158. Riggins, R.B.; Mazzotta, M.M.; Maniya, O.Z.; Clarke, R. Orphan nuclear receptors in breast cancer pathogenesis and therapeutic response. Endocr. Relat. Cancer 2010, 17, R213-R231.

(C) 2011 by the authors; licensee MDPI, Basel, Switzerland. This article is an open access article distributed under the terms and conditions of the Creative Commons Attribution license (http://creativecommons.org/licenses/by/3.0/). 